\title{
A new organizational approach to supply chain management
}

\author{
Lino Guimarães Marujo* \\ Centro Federal de Educação Tecnológica Celso Suckow da Fonseca - RJ
}

\begin{abstract}
This work examines organizational redesign of supply chain management as a tool to increase the level of service to customers. It studies the impact of the time-based concurrency phenomenon, which has forced companies to be more flexible to face the constant challenges of their markets. It also analyzes the transformation of intra-functional processes into inter-functional ones, where all departments must interact to promote an uninterrupted flow of the information inherent to organizational processes, aligned with the demands of globalized markets. Among these processes are certain key tasks and processes for more efficient supply chain management, such as management of inbound and outbound transport, administration of customer orders, materials management, production planning and management of inventories, besides technical assistance to customers when necessary. In the final analysis, companies need to adopt a new supply chain management structure.
\end{abstract}

Keywords: supply chain management, concurrency, organizational processes.

Received in 06/25/2006; revised in 08/15/2006; accept in 11/11/2006.

Corresponding author:

*linomarujo@cefet-rj.br

CEFET-RJ

Editor's note: This paper was accepted by Alexsandro Broedel Lopes. 


\section{INTRODUCTION}

$\mathrm{C}$

Companies' current administrative structures are becoming more horizontal in response to the needs of globalized markets. Customers for everything from the simplest cotton swabs to sports cars want to receive information and products with increasing speed and convenience, at ever more competitive prices.

The concept of speed is stressed by Christopher (CHRISTOPHER, 1999): "In recent years, one of the most significant developments in the way companies manage theiroperations and formulate their competitive strategies has been their focus on time. There are clearly many ways in which firms compete and through with they seek to gain advantage over their rivals. However, the ability to move quickly, whether in new product development or in replenishing customers' inventories, is increasingly recognised as a prerequisite for market-place success." Hence, response time to customer needs is increasingly moving to the fore as a competitive tool.

It is exactly this phenomenon that we address here: How can firms' organizational structures be adjusted and transformed to meet and surpass the expectations of existing and potential customers?

\section{TRADITIONAL ORGANIZATIONAL STRUCTURES}

It is very common to find, particularly in Brazilian companies, planning and control of supply chain operations through very hierarchical structures, functioning like information "silos", where information enters and exits and travels from one silo or department to another. In such a structure, important pieces of information, which should have been passed on intact, arrive at their destinations mutilated, requiring extra work to recuperate what has been lost. The end result is impaired customer service (BONTIS, 2001).

Hammer and Champy (HAMMER \& CHAMPY, 1994) state that “...the traditional business structures that employ specialist work and fragment processes are self-perpetuating, because they suffocate an organization's innovation and creativity. (...), created for another era, they are also insensitive to changes in the external environment - the market."

Rigidity and insensitivity to customers' needs, failure to focus on the customer (MOREIRA, 2002), an obsession on the activity instead of the result, bureaucratic paralysis, lack of innovation, high overhead - these characteristics have not arisen suddenly and are nothing new. They have long been present. But until recently, firms did not need to be overly concerned about these aspects. If costs were high, they could be passed through to customers, who if unsatisfied, would just have to conform. This is no longer the case, and all efforts must be focused on the new market dynamics. 
Figure 1: An example of a hierarchical structure and its main supply chain management activities

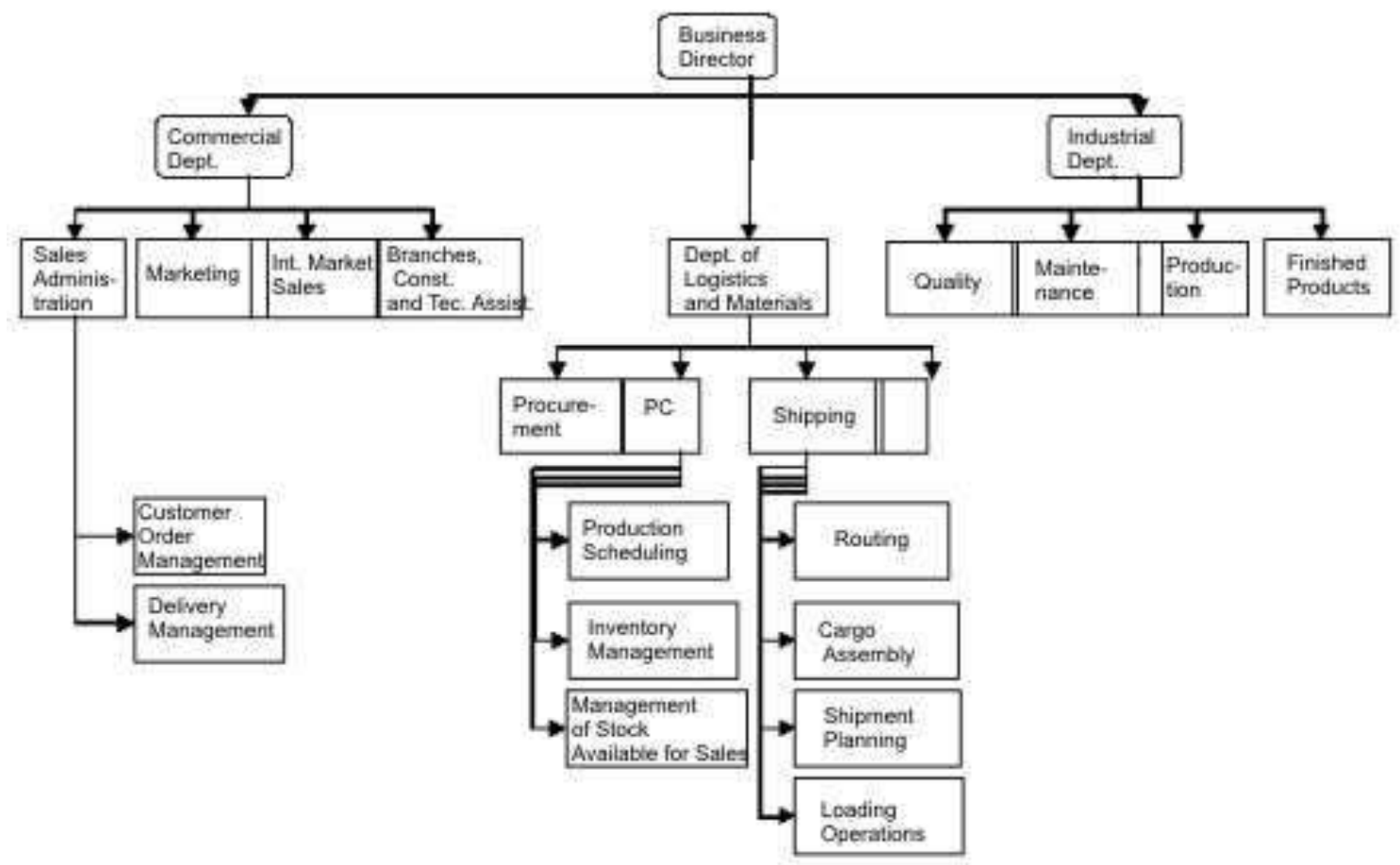

Figure 1 shows a traditional "silo" supply chain structure, where each department has fragments of customer service activity. This means that information arrives within the organization through one department, which sends it on to another, often omitting parts of this information that in each department's own judgment are "unnecessary", and so on down the line to production, shipping and delivery management activities (BONTIS et al, 1999).

The supply chain management process must be looked at as an inter-functional and inter-organizational one. Thus, its performance is constrained if it is treated from a different standpoint, and the basic objectives of better service level, reduction of inventory levels, better use of production equipment, lower maintenance costs, etc. are not heeded.

\section{THE ORGANIZATIONAL STRUCTURE MOLDED TO MARKET DEMANDS}

The key to organizational redesign of a company is to abandon the more basic notions on which it is based. Workers and managers are like prisoners of antiquated theories about how to organize work, passed down to us from the Industrial Revolution. These theories - the division of labor, the need for elaborate controls at every step, all the management hierarchy no longer function in a world where competition is global and change implacable.

In place of rigid hierarchies, specialist and hermetic activities, organizations need to be process-oriented and analyze and reformulate the key activities that create real value for their customers.

It is necessary to rethink what is fundamental and to promote a radical restructuring of management processes so that these can achieve drastically improved performance indicators, of costs, quality, service level and response time (HAMMER \& CHAMPY, 1994). 
As explained by Jack Welch, head of General Electric in its 1990 annual report: "In an organization without frontiers, suppliers are not 'strangers'. They are considered intimates and become trusted partners in the business process as a whole. Customers are considered for what they are: the basis of the company. Their needs are viewed in the same way by them and the company, and the effort of each employee is aimed at satisfying them. In this type of organization, the internal functions start to fuse. Engineering does not design a product and then 'pass the ball' to manufacturing. The two departments form a team, together with marketing, sales, finance and the others. And customer service? It's everyone's responsibility!" (CHRISTOPHER, 1999).

Joseph Boyett, in his book O Guia dos Gurus, Editora Futura, 1999 (BOYETT, 1999) also stresses the need to restructure organizations and explains some structural characteristics of high-performance organizations versus traditional ones, as shown in Table 1.

He also addresses various other organizational aspects, such as innovation and risktaking spirit, emphasis on learning, the concept of work, the role of management, customer relations, flexibility, teamwork, dedication, compensation and socio-technical balance. However, here we only look at the organizational structure aspects.

Table 1 : Traditional organizations versus high-performance organizations (BOYETT, 1999)

\begin{tabular}{ll}
\hline Traditional Organizations & High-Performance Organizations \\
\hline There are many management levels. & $\begin{array}{l}\text { There are only a few management levels between the } \\
\text { shop floor worker and upper management. The } \\
\text { organization is very horizontalized. }\end{array}$ \\
\hline $\begin{array}{l}\text { The basic organizational unit is the functional } \\
\text { department. }\end{array}$ & $\begin{array}{l}\text { The basic organizational unit is the working team. } \\
\begin{array}{l}\text { There are sharp borders between departments and/or } \\
\text { functions. }\end{array}\end{array}$ \\
$\begin{array}{ll}\text { The borders between departments and/or divisions } \\
\text { often interfere in resolving inter-functional problems. }\end{array}$ & $\begin{array}{l}\text { Resolution of inter-functional problems and } \\
\text { communication between departments are frequent. The } \\
\text { organization tries to eliminate borders. }\end{array}$ \\
\hline $\begin{array}{l}\text { Meetings are rarely held involving various levels or } \\
\text { between departments or functions. }\end{array}$ & $\begin{array}{l}\text { Inter-functional and inter-departmental meetings occur } \\
\text { often. }\end{array}$ \\
\hline $\begin{array}{l}\text { Most people would say they do not feel they are } \\
\text { managing their own business within the overall } \\
\text { organization. }\end{array}$ & $\begin{array}{l}\text { Everyone feels like they are working in a small } \\
\text { business. People work in units or teams that make a } \\
\text { complete product or offer a complete service. All fee a } \\
\text { strong identification with the product or service their } \\
\text { unit supplies. }\end{array}$
\end{tabular}

Work is segmented so that the front-line tasks The line and staff functions are totally integrated. (production, customer service, etc.) are separated from the support areas (maintenance, records, etc.) and different types of work are assigned to different departments.

Donier et al. (DONIER, 1999) propose an inter-functional approach in which supply chain management is established along three fundamental axes:

- $\quad$ management of physical activities; 
- $\quad$ management of information - data entry and processing;

- $\quad$ planning and management of operations.

Each of these axes has its own inherent activities, described generically, so that the proposed structure can mesh with and adapt to any type of organization.

For each logistical subsystem, i.e., the activities that are part of supply chain management, critical indicators are established to analyze performance, providing a yardstick for measurement.

As can be seen in Figure 2, the approach of Donier et al. contemplates the firm's entire value chain, from the physical flow of products at their origin, the first step in the chain, to their consumption, including the flow of information inherent and essential to managing the supply chain.

The figure also lists the main activities of each step, forming the basis of the new approach presented in this work. 
Figure 2: Operations in a supply chain management system (DONIER, 2000)

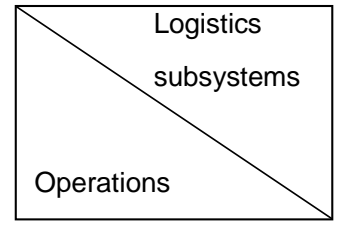

\begin{tabular}{|c|c|c|c|}
\hline $\begin{array}{c}\text { Procurement } \\
\text { (Suppliers) }\end{array}$ & $\begin{array}{c}\text { Manufacturing } \\
\text { (Plants) }\end{array}$ & $\begin{array}{c}\text { Distribution } \\
\text { (Storage, } \\
\text { Warehouses) }\end{array}$ & $\begin{array}{c}\text { After-sales } \\
\text { activities }\end{array}$ \\
\hline
\end{tabular}

Management of physical activities

Management of information

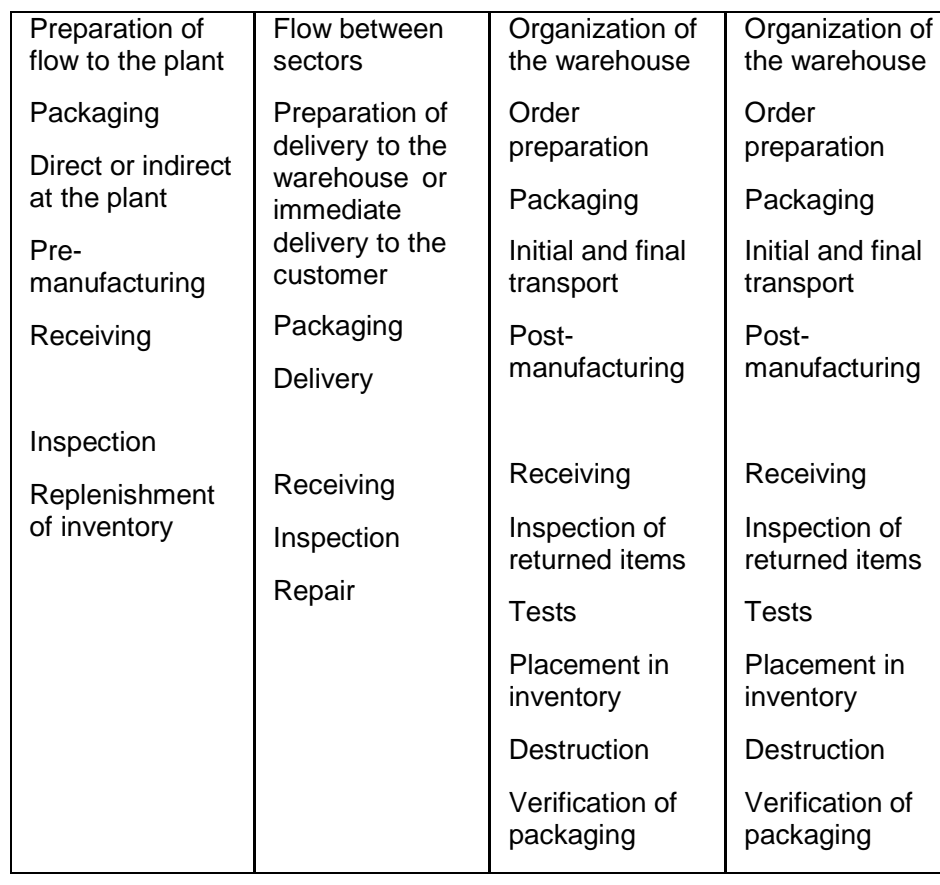

Data entry, updating, database maintenance, product packaging, customers, place of delivery

Entry of order data

Entry of data on inventory input and output

Monitoring of pre- and post-manufacturing operations

Delivery documentation

Data entry and monitoring of service level

Information on critical indicators

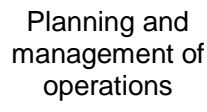

Planning and management of operations

$\begin{array}{ccc}\begin{array}{c}\text { Procurement } \\ \text { planning }\end{array} & \begin{array}{c}\text { Plant planning } \\ \text { Supply of } \\ \text { orders }\end{array} & \begin{array}{c}\text { Forecasting } \\ \text { Monitoring or } \\ \text { orders }\end{array}\end{array}$

Transport and delivery cycle

Critical analysis indicators

Supply of orders
Forecasting
Monitoring of orders of replacement parts
Planning of delivery
Supply of orders




\section{A NEW APPROACH TO SUPPLY CHAINMANAGEMENT}

As seen previously, the migration of vertical, departmentalized structures to horizontal, inter-departmental ones is a new reality being experienced by many companies today.

This new structure is a response to the new market reality, in which flows of information between various people within the organization, between its various links, to anticipate customers' expectations, are optimized so that all those involved and their interfaces can respond to market demands with agility and integration (MENTZAS et al, 2001).

Figure 3 shows this new realignment of key functions and sectors, all taken as "classic", but now taking on another meaning, to create market value and satisfy customer needs.

\section{Figure 3: Realignment of the key functions and interface sectors for supply chain} management

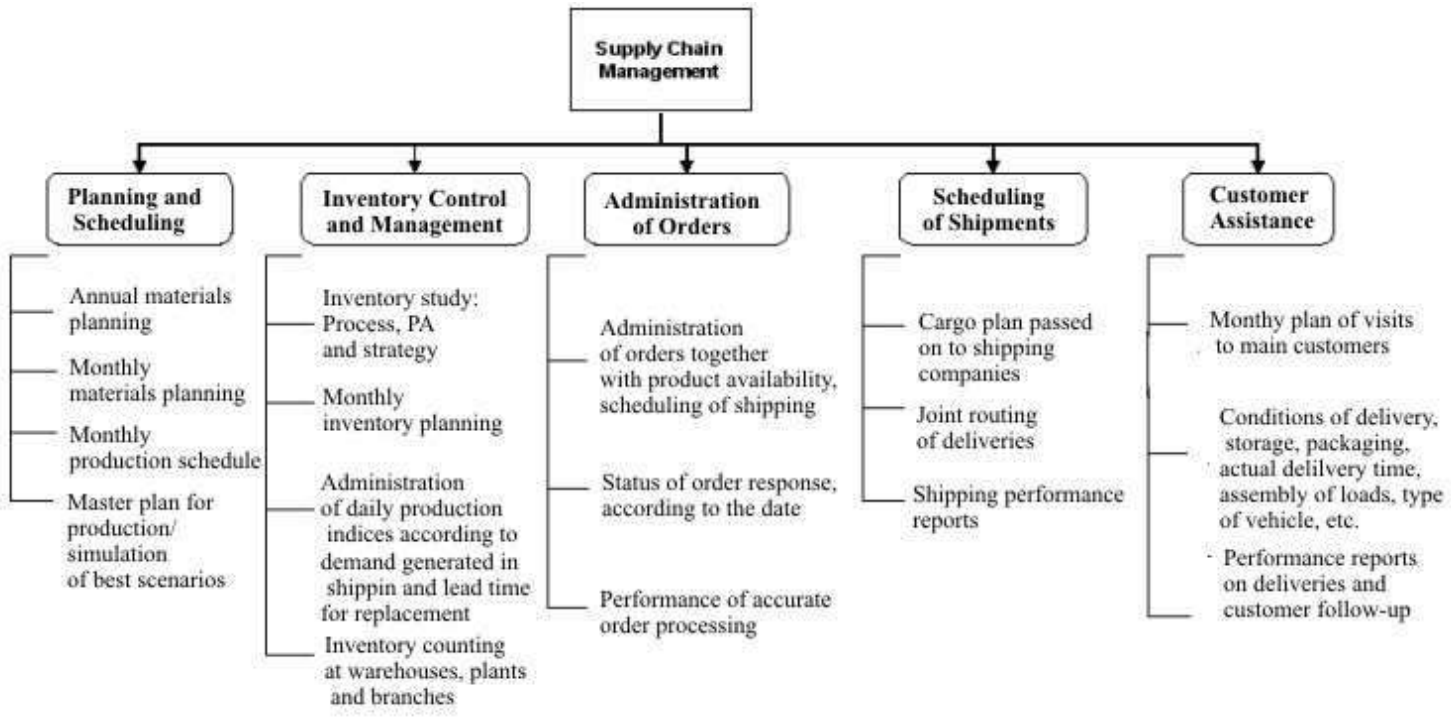

Value is created and often perceived by the customer because the entire value chain is focused on the customer and on the expectations of the company's market, providing greater flexibility and agility, in other words, faster customer response.

Each key function is associated with its main activities required to maintain a good level of customer service, and also to control the paths of the supply chain and create value for the company.

\section{CONCLUSIONS}

The new organizational approach to supply chain management poses a big challenge to traditional organizations, since they have to remake themselves and break old paradigms, such as departmentalization, division of responsibilities and hierarchies.

However, the expected gains from increased ability to adapt the supply chain, with quicker decisions based on the information and knowledge generated by all those involved in 
the shared and accessible process far surpass the possible "traumas" of breaking these paradigms.

This work is merely a brief introduction to subject. Only a more detailed study of the best market practices can validate the general recommendations made here, but the effort is certainly worthwhile for companies to become national and even international references of excellence.

\section{REFERENCES}

BONTIS, Nick. "CKO Wanted - Evangelical Skills Necessary: A Review of the Chief Knowledge Officer Position”, Journal of Knowledge and Process Management, v. 8, n. 1, pp. 29-38, 2001.

BONTIS, Nick, DRAGONETTI, Nicola C., JACOBSEN, Kristine, ROOS, Göran. "The Knowledge Toolbox: a review of the tools available to measure and manage intangible resources", European Management Journal, v. 17, n. 4, pp. 391-402, 1999.

BOYETT, Joseph, BOYETT, Jimmie. O Guia dos Gurus: Os melhores conceitos e práticas de negócios. 6th Ed., Campus, Rio de Janeiro, 1999.

CHRISTOPHER, Martin. O Marketing da Logística, 1st Ed, São Paulo, Futura, 1999.

HAMMER, Michel, CHAMPY, James. Reengenharia: Revolucionando a Empresa. 26th Ed, Campus, Rio de Janeiro, 1994.

DONIER, Philippe-Pierre et al. Logística e Operações Globais: textos e casos. 1st Ed., Atlas, São Paulo, 2000.

MOREIRA, J. Carlos T. "Satagite". Revista de Marketing Industrial. n. 20, pp. 6-13, Ed. Instituto de Marketing Industrial, São Paulo, 2002.

MENTZAS, Gregoris, APOSTOLOU, Dimitris, YOUNG, Ronald, ABECKER, Andreas. "Knowledge networking: a holistic solution for leveraging corporate knowledge", Journal of Knowledge Management, v. 5, n. 1, pp. 94-106, 2001.

PORTER, Michael E. Vantagem Competitiva: criando e sustentando um desempenho superior. 13th Ed, Campus, Rio de Janeiro, 1989.

SLACK, Nigel et al. Operations Management, 1st Ed., Pitman Publishing, London, UK, 1997. 